\title{
Water Balance and Profile Moisture Loss Patterns of an Alfisol ${ }^{1}$
}

Piara Singh and M. B. Russel1 ${ }^{2}$

\begin{abstract}
In order to match the water availability with the crop water requirement in the semi-arid tropical (SAT) areas of the world, the distribution and magnitude of various water balance components and the moisture dynamics in the soil profile during crop growth periods need to be understood. Since Alfisols (fine, clayey mixed udic Rhodustalf) constitute the major soil group of SAT areas, its water balance and water loss pattern in sorghum ( $S$. bi. color $L$. Moench) was studied during both the monsoon and post-monsoon season of 1977 to 1978 .

During the monsoon season, water losses as evaporation, transpiration, and drainage constituted 21,35 , and $29 \%$, respectively, of the total seasonal available water (Rainfall + irrigation + profile available water to $127 \mathrm{~cm}$ depth). In the post-monsoon season, the only unproductive loss of water was soil evaporation which formed about one-fourth of the total seasonal available water. The major amount of moisture depletion during the postmonsoon season was confined to the top $90 \mathrm{~cm}$ profile depth.

The data obtained on water balance and the ability of Alfisols to supply water to crops suggest the need for better water management by adopting improved cultural practices, like water harvesting, and improved cropping patterns for optimizing water availability and its use for crop production in the SAT.
\end{abstract}

Additional index words: Estimated evaporation, Transpiration, Drainage, Rainfall efficiency.

\footnotetext{
${ }^{1}$ Contribution from the International Crops Res. Inst. for the Semi-Arid Tropics, Hyderabad, India. Submitted as ICRISAT Journal Paper No. 28. Received 19 Apr. 1978.

${ }^{2}$ Soil scientist and consultant in soil physics, respectively.
}

THE semi-arid tropical (SAT) areas of the world 1 have erratic rainfall, both in terms of its occurrence and intensity. The supply of plant available water is undependable and agricultural production in these areas is low and unstable. High rainfall intensity, coupled in many areas with low permeability of the soils, causes excessive run off and soil erosion which further reduces the quantity of water in the soil profile available for crop production. To improve the rainfall efficiency and to better understand the crop responses to moisture variation in these areas, a more detailed, quantitative description of all components of the water balance equation and their changes during the season are needed. Several water balance models have been developed in the past based on meteorologic, crop, and soil moisture relationship on a daily basis in order to predict evapotranspiration and soil moisture $(1,3,4,5,6)$.

In semi-arid parts of India, major crops like sorghum (S. bicolor L. Moench) depend on rainfall for its water needs in the monsoon season. During the post-monsoon season, crops depend on residual profile moisture storage and supplemental irrigation. Under such climatic conditions proper accounting of profile moisture changes is important for crop planning and predicting plant behavior in these areas. Therefore, we chose to study the water balance and profile water loss pattern of an Alfisol cropped to sorghum during both the monsoon and post-monsoon season. Rainfall, open pan evaporation, runoff, and time and depth changes in profile water content were measured, and drainage, evaporation, and transpiration losses computed. 


\section{MATERIALS AND METHODS}

The experiment was conducted during both the monsoon and post-monsoon season of 1977 to 1978 at the ICRISAT research center near Hyderabld, India. The soil is a medium, deep Alfisol, which has been classified as fine, clayey mixed, member of the hyperthermic family of udic Rhodustalfs. Water retention at field capacity (in situ) in the upper $127 \mathrm{~cm}$ profile is $300 \mathrm{~mm}$ and at 15 bar is $120 \mathrm{~mm}$. Soil is low in organic matter, $N, P$, and often $\mathrm{Zn}$. The $K$ level is adequate and $\mathrm{pH}$ is 6.7 .

\section{Monsoon Season Trial}

CSH-6 Sorghum was planted on 7 July 1977 in an experiment having eight replications. Before planting, the field was cultivated and prepared to meter-wide beds separated by $50 \mathrm{~cm}$ furrows. It was then divided into eight $9 \times 15 \mathrm{~m}$ plots each having six beds. Each plot was diked to prevent runoff. Seventy-five $\mathrm{kg} / \mathrm{ha}$ of 18-46-0 were drilled in the rows before planting Three $50 \mathrm{~cm}$ rows of sorghum were planted on each bed and later thinned to eight plants per meter. Ammonium sulphate at 50 and $75 \mathrm{~kg} / \mathrm{ha}$ was side-dressed 9 and 44 days after planting, respectively.

To monitor soil moisture, six neutron probe access tubes per plot were installed midway between sorghum rows and uniformly distributed all over the plot. Probe observations were taken at $15 \mathrm{~cm}$ intervals from 30 to $180 \mathrm{~cm}$ depth every 14 days. Moisture in the 0 to 10 and 10 to $22 \mathrm{~cm}$ layers was measured gravimetrically on the same schedule. Tensiometers were installed at 120 and $150 \mathrm{~cm}$ depths to monitor changes in the water potential and potential gradient at these depths. Rainfall was measured by a gauge adjacent to the plot area. Open-pan evaporation and other weather parameters were obtained from the ICRISAT meterological station about $1 \mathrm{~km}$ from the plot area. Plant samples were taken periodically from predetermined areas to determine leaf area by a portable leaf area meter (Model LI-3000) and leaf area index (LAI) calculated. Fractional net radiation at the soil surface $\left(\mathbf{R}_{n \mathbf{n}}\right)$ $R_{n o}$ ) was calculated from the following relationship given by Ritchie (3).

$\mathbf{R}_{\mathrm{ng}} / \mathbf{R}_{\mathrm{no}}=\mathrm{e}^{-.898 \mathrm{~L} \boldsymbol{A} 1}$ where $\mathbf{R}_{\mathrm{ng}}$ and $\mathbf{R}_{\mathrm{no}}$ are net-radiation reaching at the soil surface, and above the canopy, respectively.

\section{Post-Monsoon Season Trial}

After harvesting the monsoon crop, the plots were cultivated and levelled. Sorghum (CSH-8) was planted on 7 November 1977 in $35 \mathrm{~cm}$ wide rows in four plots which had grown only sorghum in the previous season. One-hundred seventy $\mathrm{kg} / \mathrm{ha}$ of 18-46.0 were drilled prior to planting. Plants were thinned to $12 \mathrm{~cm}$, and $30 \mathrm{~kg} / \mathrm{ha}$ of urea was side-dressed 22 days after planting. The tensiometers and neutron probes were monitored periodically as in the monsoon season. A $7 \times 5 \mathrm{~m}$ area per plot was harvested as fodder on 19 January.

Evaporation and transpiration were estimated by the energy balance method. Briefly, estimates of daily soil evaporation and transpiration were made from the following relationships:

$$
\mathbf{E}^{*}=\mathbf{E}_{\mathrm{v}} / \mathrm{t} ; \mathbf{E}=\mathbf{E}^{*}\left(\frac{\mathbf{R}_{\mathrm{na}}}{\mathbf{R}_{\mathrm{no}}}\right) ; \text { and } \mathrm{T}_{\mathrm{e}}=\left(1-\frac{\mathbf{R}_{\mathrm{na}}}{\mathbf{R}_{\mathrm{no}}}\right) \mathbf{E}_{\mathrm{o}}
$$

where $\mathbf{E}^{*}$ is potential evaporation from a bare soil (mm), $\mathrm{E}_{0}=$ open pan evaporation $(\mathrm{mm}) \mathrm{t}=$ number of days after a recharging rain (dimensionless), $\mathbf{E}=$ soil evaporation under a crop canopy $(\mathbf{m m}), \mathbf{R}_{\mathrm{ng}} / \mathbf{R}_{\mathrm{no}}=$ fractional net radiation received by the soil surface (dimensionless) and $T_{e}=$ estimated potential transpiration based on energy balance $(\mathrm{mm})$. On the day when total rainfall plus antecedent profile moisture exceeded the storage capacity of the soil to a specified depth, the excess water was considered as drainage.

To calculate the transpiration for a given period, evaporation and profile drainage were subtracted from the rainfall plus total profile water change to $127 \mathrm{~cm}$ depth $\left(\Delta \mathrm{M}_{12 \pi}\right)$ for that period to give the "mass balance transpiration" $\left(\mathrm{T}_{\mathrm{m}}\right)$.

\section{RESULTS}

\section{Water Balance}

The water balance components during different periods for both monsoon and post-monsoon seasons are presented in Table 1. During the monsoon season, soil evaporation was a significant part of the water loss from the sorghum plots, which constituted $21 \%$ of the total seasonal available water. Cumulative evaporation remained higher than the cumulative transpiration until about 41 days after planting. In the latter part of the growing season, transpiration was the major source of water loss. A significant amount of drainage beyond $127 \mathrm{~cm}$ occurred during August and early September. This is also supported by the development of very low water tensions at $135 \mathrm{~cm}$ soil depth (Fig. 1). From September 5 to 12 , the drainage slowed, which was also indicated by the development of very low water potentials and upward-acting gradients at 135 cm depth (Fig. 1).

Table 1. Monsoon and post-monsoon water balance components (mm) for an Alfisol.

\begin{tabular}{|c|c|c|c|c|c|c|c|c|c|c|}
\hline \multirow[b]{3}{*}{ Calender period } & \multicolumn{4}{|c|}{ Location variables } & \multirow{2}{*}{\multicolumn{6}{|c|}{ Treatment variables }} \\
\hline & \multirow{2}{*}{$\begin{array}{c}\text { Days since } \\
\text { planting }\end{array}$} & \multirow[b]{2}{*}{ Rainfall } & \multirow[b]{2}{*}{$\mathrm{E}_{0}$} & \multirow[b]{2}{*}{$\mathrm{E}^{*}$} & & & & & & \\
\hline & & & & & \multirow[t]{2}{*}{ Irrigation } & \multirow[t]{2}{*}{$\Delta \mathrm{M}_{127}$} & \multirow[t]{2}{*}{$\mathbf{E}$} & \multirow[t]{2}{*}{$\mathrm{D}_{127}$} & \multirow[t]{2}{*}{$\mathrm{T}_{\mathrm{m}}$} & \multirow[t]{2}{*}{$\mathbf{T}_{\mathbf{e}}$} \\
\hline \multicolumn{5}{|c|}{ Monsoon sorghum } & & & & & & \\
\hline $\begin{array}{l}\text { 13-18 July } \\
\text { 18-28 July } \\
28 \text { July-4 Aug. } \\
\text { 4-16 Aug. } \\
\text { 16 Aug.-5 Sept. } \\
\text { 5-12 Sept. } \\
\text { 12-26 Sept. }\end{array}$ & $\begin{array}{l}7 \text { to } 12 \\
12 \text { to } 22 \\
22 \text { to } 29 \\
29 \text { to } 41 \\
41 \text { to } 61 \\
61 \text { to } 68 \\
68 \text { to } 82\end{array}$ & $\begin{array}{r}50 \\
56 \\
16 \\
97 \\
124 \\
- \\
-\end{array}$ & $\begin{array}{l}37 \\
42 \\
37 \\
54 \\
73 \\
38 \\
83\end{array}$ & $\begin{array}{r}10 \\
38 \\
22 \\
19 \\
54 \\
7 \\
5\end{array}$ & $\begin{array}{l}- \\
- \\
- \\
- \\
- \\
- \\
-\end{array}$ & $\begin{array}{r}29 \\
10 \\
-16 \\
6 \\
7 \\
-42 \\
-16\end{array}$ & $\begin{array}{r}10 \\
36 \\
19 \\
10 \\
13 \\
1 \\
1\end{array}$ & $\begin{array}{l}- \\
6 \\
1 \\
54 \\
54 \\
10 \\
-\end{array}$ & $\begin{array}{r}11 \\
4 \\
12 \\
27 \\
50 \\
31 \\
15\end{array}$ & $\begin{array}{r}- \\
1 \\
5 \\
23 \\
55 \\
32 \\
62\end{array}$ \\
\hline Total & & 343 & 364 & 155 & & -22 & 90 & 125 & 150 & 178 \\
\hline$\%$ of total seasonal available water & & & & & & & 21 & 29 & 35 & 41 \\
\hline \multicolumn{11}{|c|}{ Post-monsoon sorghum } \\
\hline $\begin{array}{l}\text { 7-16 Nov. } \\
16 \text { Nov.-1 Dec. } \\
\text { 1-28 Dec. } \\
28 \text { Dec.-7 Jan. } \\
\text { 7-18 Jan. }\end{array}$ & $\begin{array}{l}0 \text { to } 10 \\
10 \text { to } 25 \\
25 \text { to } 52 \\
52 \text { to } 62 \\
62 \text { to } 73\end{array}$ & $\begin{array}{r}5 \\
6 \\
2 \\
-\quad 17\end{array}$ & $\begin{array}{r}53 \\
61 \\
125 \\
47 \\
43\end{array}$ & $\begin{array}{r}12 \\
12 \\
12 \\
1 \\
18\end{array}$ & $\begin{array}{l}\overline{22} \\
- \\
- \\
-\end{array}$ & $\begin{array}{r}-17 \\
6 \\
-44 \\
-11 \\
-9\end{array}$ & $\begin{array}{r}12 \\
10 \\
7 \\
- \\
9\end{array}$ & $\begin{array}{l}- \\
- \\
- \\
-\end{array}$ & $\begin{array}{l}10 \\
12 \\
39 \\
11 \\
17\end{array}$ & $\begin{array}{r}1 \\
9 \\
51 \\
25 \\
21\end{array}$ \\
\hline Total & & 30 & 329 & 55 & 22 & -75 & 38 & - & 89 & 107 \\
\hline$\%$ of total seasonal available water & & & & & & & 23 & & 53 & 64 \\
\hline
\end{tabular}


In the post-monsoon season, evaporation constituted $23 \%$ of the total seasonal available water. During the first 25 days of planting, evaporation was equal to transpiration and later in the season, major water loss was by transpiration. Transpiration constituted $53 \%$ of the total seasonal available water. No drainage was observed during the post-monsoon season. Significant difference in the estimates of transpiration by the energy balance method and mass balance method (Table 1), suggests that the crop remained under stress in the later part of the growing season.

\section{Moisture Depletion Patterns}

Available water (total water storage above 15 bar) in the upper $127 \mathrm{~cm}$ profile at planting was $90 \mathrm{~mm}$ at the beginning of the monsoon season. This constituted $68 \%$ of the total available soil capacity to that depth. Since soil evaporation, transpiration, and drainage were occurring simultaneously, it is very difficult to arrive at any definite pattern of soil moisture depletion by crop during this period (Fig. 2). However, during the relatively rainfree period of 5 to 22 September, there was a continuous loss of moisture at all depths in the profile. From September 12 to 26 losses as transpiration from the 0 to 22,22 to 52,52 to 82 , and 82 to $127 \mathrm{~cm}$ layers were $29,31,21$, and $23 \%$, respectively.

At the beginning of the post-monsoon season, available water in the top $127 \mathrm{~cm}$ of profile was $115 \mathrm{~mm}$. This represented $87 \%$ of total available capacity of the $127 \mathrm{~cm}$ profile. Average depletion from 0 to 22,22 to 52,52 to 82 and 82 to $127 \mathrm{~cm}$ layers were $38,31,16$, and $14 \%$, respectively. With the drying of top soil

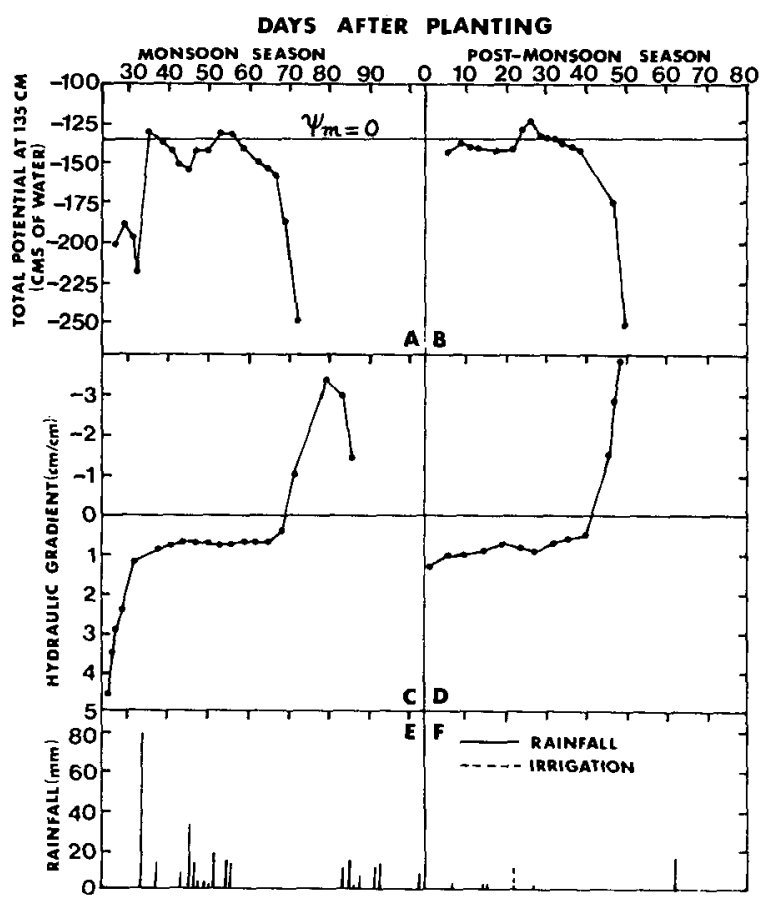

Fig. 1. Total water potential and gradients at $135 \mathrm{~cm}$ profile depth in the monsoon season $(A, C)$ and post-monsoon season (B, D) sorghum. $\psi_{m}$ means matrix potential. during 28 December to 18 January, contribution of the 82 to $127 \mathrm{~cm}$ layer to the total transpiration for that period increased to $30 \%$.

\section{Yield and Water Use Efficency}

The grain and stover yields of the monsoon sorghum were 37 and $145 \mathrm{q} / \mathrm{ha}$, respectively. On the basis of total transpiration $(\mathrm{Tm})$, the water use efficiencies (WUE) of grain and stover were 2.5 and $9.9 \mathrm{q} / \mathrm{ha}$ per $\mathrm{cm}$, respectively. The water transpired by the crop represented $35 \%$ of the total seasonal available water.

The post-monsoon season stover yields were 44.9 $\mathrm{q} / \mathrm{ha}$. Water use efficiency on the basis of seasonal transpiration $(\mathrm{Tm})$ was $4.8 \mathrm{q} / \mathrm{ha}$ per $\mathrm{cm}$.

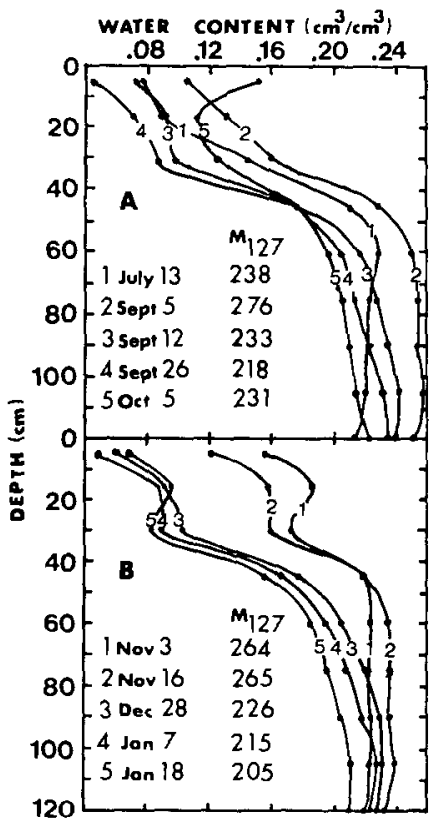

Fig. 2. Time and depth pattern of moisture depletion by monsoon season (A) and post-monsoon season (B) sorghum. $\mathbf{M}_{12 \pi}$ means moisture storage in $\mathrm{mm}$ in the top $127 \mathrm{~cm}$ soil profile.

\section{DISCUSSION}

High water losses as evaporation and drainage during the monsoon season $50 \%$ of total seasonal available water) suggest the need for better water management in these areas. This could be achieved by reducing soil evaporation by choosing better cropping systems which would provide enough ground cover and deeper rooting crops for exploiting the profile water better. Because of low-input agriculture in these areas, use of mulches does not seem to be a better choice for checking soil evaporation. Since all the plots in the present study were diked to prevent runoff, the drainage reported here has been overestimated since, infact, it represents both runoff and drainage. In a recent report, Krantz et al. (2), suggested the possibilities of water harvesting on Alfisols during the monsoon season, and its subsequent use for the post- 
monsoon season crops to increase the rainfall use effiency and to decrease soil erosion. Such an evidence of significant runoffs could not be demonstrated in this study due to limitations on the availability of instrumentation to measure runoff. During the postmonsoon season, difference between the transpiration values, as obtained by the energy balance and mass balance methods, suggest that the crop was stressed, especially in the later crop part of the season. This could be avoided by providing supplemental irrigation of the harvested water or by minimizing the soil evaporation which constituted $23 \%$ of the total seasonal available water.

Though the major amount of profile water depletion was confined to the top $90 \mathrm{~cm}$, there seems to be some contribution of layers below $90 \mathrm{~cm}$ to the total transpiration of rainfed sorghum as indicated by negative tension and upward-acting gradient developments later in the season at $135 \mathrm{~cm}$ depth and below indicating upward flux into the root zone (Fig. 1). For the lack of data on the unsaturated conductivity of these soils estimates on the upward flux and its contribution to evapotranspiration could not be made. It does suggest that some late-season depletion may have been underestimated. If that's true, then the water use efficiency (grain yield per hectare per $\mathrm{cm}$ of transpiration) and drainage values for monsoon sorghum and rainfed sorghum have been overestimated.

In spite of increased contribution of sub-soil to the evapotranspiration of sorghum later in the season, the end of season profile moisture distribution (Fig. 2) indicates that the available profile water storage re- mained underutilized by sorghum in both seasons. This could be due to inadequate root development in lower horizons of these soils.

The above study on water balance and profile water use suggests the need to investigate methods to improve rainfall and profile water use efficiency on Alfisols.

\section{ACKNOWLEDGMENT}

ICRISAT receives support from IBRD, IDRC, UNDP, USAID, and a variety of other donors, governments, and foundations. All responsibility for the information in this publication rests with ICRISAT.

\section{LITERATURE CITED}

1. Kanemasu, E. T., L. R. Stone, and W. L. Powers. 1976. Evapotranspiration model tested for soybean and sorghum. Agron. J. 68:569-572.

2. Krantz, B. A., J. Kampen, and S. M. Virmani. 1978. Soil and water conservation and utilization for increased food production in the semi-arid tropics. Int. Congr. Soil Sci. Trans. 11th (Edmonton, Canada) I:327.

3. Ritchie, J. T. 1972. Model for predicting evaporation from a row crop with incomplete cover. Water Resour. Res. 8: 1204-1213.

4. Rosenthal, W. D., E. T. Kanemasu, R. J. Raney, and L. F. Stone. 1977. Evaluation of an evapotranspiration model for corn. Agron. J. 69:461-464.

5. Saxton, K. E., H. P. Johnson, and R. H. Shaw. 1974. Modeling evapotranspiration and soil moisture. Trans. Am. Soc. Agric. Eng. 17:673-677.

6. Tanner, C. B., and W. A. Jury. 1976. Estimating evaporation and transpiration from a row crop during incomplete cover. Agron. J. 68:239-243. 